\title{
Carbon Monoxide as an Electron Donor for the Biological Reduction of Sulphate
}

\author{
Sofiya N. Parshina, ${ }^{1}$ Jan Sipma, ${ }^{2}$ Anne Meint Henstra, ${ }^{3}$ and Alfons J. M. Stams ${ }^{3}$ \\ ${ }^{1}$ Laboratory of Microbiology of Anthropogenic Environments, Winogradsky Institute of Microbiology, \\ Russian Academy of Sciences, 117312, prosp. 60 let Oktyabrya, 7, b.2, Moscow, Russia \\ ${ }^{2}$ Laboratory of Chemical and Environmental Engineering (LEQUIA), University of Girona, 17071 Girona, Spain \\ ${ }^{3}$ Laboratory of Microbiology, Wageningen University, $6703 \mathrm{HB}$, Wageningen, The Netherlands \\ Correspondence should be addressed to Sofiya N. Parshina, sonjaparshina@mail.ru
}

Received 1 October 2009; Revised 10 March 2010; Accepted 31 March 2010

Academic Editor: Michael J. McInerney

Copyright (๑) 2010 Sofiya N. Parshina et al. This is an open access article distributed under the Creative Commons Attribution License, which permits unrestricted use, distribution, and reproduction in any medium, provided the original work is properly cited.

\begin{abstract}
Several strains of Gram-negative and Gram-positive sulphate-reducing bacteria (SRB) are able to use carbon monoxide (CO) as a carbon source and electron donor for biological sulphate reduction. These strains exhibit variable resistance to CO toxicity. The most resistant SRB can grow and use CO as an electron donor at concentrations up to $100 \%$, whereas others are already severely inhibited at $\mathrm{CO}$ concentrations as low as $1-2 \%$. Here, the utilization, inhibition characteristics, and enzymology of CO metabolism as well as the current state of genomics of CO-oxidizing SRB are reviewed. Carboxydotrophic sulphate-reducing bacteria can be applied for biological sulphate reduction with synthesis gas (a mixture of hydrogen and carbon monoxide) as an electron donor.
\end{abstract}

\section{Introduction}

Sulphate reducers are anaerobic microorganisms that are able to use sulphate as a terminal electron acceptor [1]. They are widespread in anoxic habitats [2] and can use numerous substrates as electron donor for growth. These include sugars [3, 4], amino acids [5, 6], hydrogen [7], and one-carbon compounds, such as methanol [8-11], carbon monoxide [12-14], and methanethiol [15]. Even alkanes [16-19], alkenes [20], and short-chain alkanes [21], as well as aniline [22], benzoate, phenol, aromatic hydrocarbons [2325], and phosphite [26] are used as electron donor.

Sulphate-reducing bacteria play an important role in biodesulfurization processes. Industries that use sulphuric acid, sulphate-rich feedstocks, or reduced sulphur compounds generate wastewaters rich in sulphate [27]. Sulphate is removed from wastewater by the combined activity of SRB that generate sulphide and the subsequent partial oxidation of sulphide to insoluble elemental sulphur by sulphide oxidizing bacteria [28]. Biotechnological applications of sulphate reduction further include $\mathrm{SO}_{x}$ abatement from the flue gas of coal fueled power plants [27] and treatment of sulphate-rich, heavy metal contaminated wastewaters. Heavy metals such as $\mathrm{Cu}, \mathrm{Zn}, \mathrm{Cd}, \mathrm{Pb}, \mathrm{Ni}$, and $\mathrm{Fe}$ can be removed from waste streams by precipitation with biogenic sulfide. Because of differences in solubility of products, the metals can be selectively precipitated, which enables their recovery and reuse as demonstrated at full-scale for a zinc smelting plant [29].

If sulphate-rich wastewaters contain no or insufficient amounts of suitable electron and carbon donors for sulphate reduction, external addition becomes a prerequisite. Examples of such wastewaters are waste streams generated in galvanic processes, in the detoxification of metal-contaminated soils, in the mining of heavy metals and coal, and in flue gas desulphurization [30]. The selection of the most appropriate electron donor depends on its sulphate reduction efficiency, costs, and residual pollution. The use of simple organic compounds (e.g., ethanol or methanol) or $\mathrm{H}_{2} / \mathrm{CO}_{2}$ is highly preferred over complex wastes, for example, molasses, tannery effluents, solid waste materials, and manure [27]. Especially $\mathrm{H}_{2}$ is often used for biotechnological sulphate reduction. Van Houten et al. [31] demonstrated that with a mixture of $\mathrm{H}_{2} / \mathrm{CO}_{2}(80 \%: 20 \%)$, sulphate reduction rates 
as high as $30 \mathrm{~g} \mathrm{SO}_{4}{ }^{2-} \mathrm{L}^{-1} \mathrm{~d}^{-1}$ are achieved within 10 days of operation in gas lift bioreactors. Alternatively, synthesis gas or methane can be used; however, the sulphate reduction rates with methane are still extremely low. Synthesis gas, a mixture of $\mathrm{H}_{2}, \mathrm{CO}$ and $\mathrm{CO}_{2}$ and some other trace gases [32], has been considered a cheap alternative for high-purity $\mathrm{H}_{2}$. Synthesis gas can be used either directly or after enriching its $\mathrm{H}_{2}$ content by means of a water-gas shift reaction, that is, the catalytic reaction in which $\mathrm{CO}$ is forced to react with water yielding carbon dioxide and hydrogen [33]. In addition, residual electron donors or side products should be low or easily removed. Here, we review the growth of SRB with $\mathrm{H}_{2} / \mathrm{CO}$ mixtures and with pure $\mathrm{CO}$.

\section{CO in the Metabolism of SRB}

2.1. CO as an Electron Donor for Pure Cultures of SRB. Some pure cultures of hydrogen-utilizing sulphate-reducing bacteria are able to use carbon monoxide as a carbon and energy source [34-36]. A few species of mesophilic sulphatereducers can grow at low concentrations $(4.5-20 \%)$ of CO. The most tested CO-utilizing SRB are species of genera Desulfovibrio and Desulfotomaculum (Table 1). The following reactions (Gibbs energy, $\Delta \mathrm{G}^{\circ \prime}$ ), calculated according to [37] play a role during growth of SRB on CO:

$$
\begin{aligned}
& 4 \mathrm{CO}+\mathrm{SO}_{4}{ }^{2-}+4 \mathrm{H}_{2} \mathrm{O} \longrightarrow 4 \mathrm{HCO}_{3}{ }^{-}+\mathrm{HS}^{-}+3 \mathrm{H}^{+} \\
& \Delta \mathrm{G}^{\circ \prime}=-37.1 \mathrm{~kJ} / \mathrm{mol} \mathrm{CO}, \\
& 4 \mathrm{CO}+4 \mathrm{H}_{2} \mathrm{O} \longrightarrow \text { acetate }^{-}+2 \mathrm{HCO}_{3}{ }^{-}+3 \mathrm{H}^{+} \\
& \Delta \mathrm{G}^{\circ \prime}=-28.2 \mathrm{~kJ} / \mathrm{mol} \mathrm{CO}, \\
& \mathrm{CO}+2 \mathrm{H}_{2} \mathrm{O} \longrightarrow \mathrm{HCO}_{3}{ }^{-}+\mathrm{H}_{2}+\mathrm{H}^{+} \\
& \Delta \mathrm{G}^{\circ \prime}=-15 \mathrm{~kJ} / \mathrm{mol} \mathrm{CO}, \\
& 4 \mathrm{H}_{2}+\mathrm{SO}_{4}{ }^{2-}+\mathrm{H}^{+} \longrightarrow \mathrm{HS}^{-}+4 \mathrm{H}_{2} \mathrm{O} \\
& \Delta \mathrm{G}^{\circ \prime}=-45.2 \mathrm{~kJ} / \mathrm{mol} \mathrm{H}_{2}, \\
& 4 \mathrm{H}_{2}+2 \mathrm{HCO}_{3}{ }^{-}+\mathrm{H}^{+} \longrightarrow \text { acetate }^{-}+4 \mathrm{H}_{2} \mathrm{O} \\
& \Delta \mathrm{G}^{\circ \prime}=-36.4 \mathrm{~kJ} / \mathrm{mol} \mathrm{H}_{2} .
\end{aligned}
$$

First information on CO oxidation by thermophilic Desulfotomaculum species was published in 1985 by Klemps et al. [8]. These moderately thermophilic Desulfotomaculum species could grow slowly with CO (4$20 \% \mathrm{v} / \mathrm{v}$ ) as the only energy source. Four thermophilic sulphate-reducing bacteria: Desulfotomaculum thermoacetoxidans strain CAMZ, Thermodesulfovibrio yellowstonii, Desulfotomaculum kuznetsovii, and Desulfotomaculum thermobenzoicum subsp. Thermosyntrophicum were studied in pure culture and in coculture with the thermophilic carboxydotrophic hydrogenogenic bacterium Carboxydothermus hydrogenoformans [12]. In pure culture, Dtm. kuznetsovii and Dtm. thermobenzoicum subsp. thermosyntrophicum were able to grow with $\mathrm{CO}$. In the presence of hydrogen and carbon dioxide, $\mathrm{CO}$ concentrations as high as $50-70 \%$ were utilized. The latter two SRB coupled CO oxidation to sulphate reduction without intermediate $\mathrm{H}_{2}$ production (reaction (1)), but a large part of the $\mathrm{CO}$ was converted to acetate (reaction (2)). When grown in coculture with the carboxydotrophic bacterium C. hydrogenoformans [44], Dtm. kuznetsovii and Dtm. thermobenzoicum subsp. thermosyntrophicum could grow with $100 \%$ CO $\left(\mathrm{P}_{\mathrm{CO}}=120 \mathrm{kPa}\right)$ [12]. In that experiment, hydrogen was formed from CO by C. hydrogenoformans (reaction (3)) and subsequently the sulphate-reducers used the generated hydrogen as electron donor (reaction (4)).

Dtm. carboxydivorans strain CO-1-SRB ${ }^{T}$ was isolated from an anaerobic bioreactor treating wastewater from several paper mills [13]. The bacterium could grow with $100 \%$ CO in the gas phase. In the presence of sulphate, CO was converted to $\mathrm{H}_{2}$ and $\mathrm{CO}_{2}$ and the generated $\mathrm{H}_{2}$ was used for sulphate reduction. In the absence of sulphate, $\mathrm{CO}$ was completely converted to $\mathrm{H}_{2}$ and $\mathrm{CO}_{2}$. Phylogenetically it was placed between Dtm. nigrificans and Desulfotomaculum sp. RHT-3 [45-47]. Desulfotomaculum sp. RHT-3 could utilize up to $50 \%$ CO maximally [13], whereas Dtm. nigrificans could grow up to $20 \%$ CO maximally, as was found before by Klemps et al. [8]. Higher concentrations completely inhibited their growth [13].

Archaeoglobus fulgidus is a thermophilic sulphate reducing Archaeon able to grow on several organic substrates $[42,43]$. Recently, the ability of $A$. fulgidus to grow with $\mathrm{CO}$ and to couple growth on $\mathrm{CO}$ with sulphate reduction was demonstrated [14]. Sulphate is reduced with $\mathrm{CO}$ as electron donor without intermediate $\mathrm{H}_{2}$ production, but with transient formate formation. Additionally A. fulgidus grows acetogenically with $\mathrm{CO}$ in the presence and absence of sulphate and sulphate reduction to sulphide is not inhibited by $\mathrm{CO}[14]$.

2.2. CO Toxicity to SRB. CO is a substrate, but also an inhibitor of sulphate-reducing bacteria. The inhibiting CO concentration ranges from $2 \%$ up to $70 \%$ for different SRB. It was found that Desulfovibrio desulfuricans, growing on lactate and sulphate, tolerated a $\mathrm{CO}$ concentration up to $20 \%$, although such a CO concentration caused a reversible type of growth inhibition [40,48] (Table 1). Desulfovibrio africanus, Desulfovibrio baculatus, and some Desulfovibrio desulfuricans strains grow with lactate in the presence of $20 \%$ or less of CO. Higher CO concentrations inhibited growth completely [40]. CO concentrations exceeding $20 \%(\mathrm{v} / \mathrm{v})$ inhibited growth of Desulfosporosinus orientis completely [8]. Growth of Dtm. thermoacetoxidans and T. yellowstonii with pyruvate was completely inhibited at $\mathrm{CO}$ concentrations as low as $2 \%$ in the gas phase [12], whereas Dtm. kuznetsovii and Dtm. thermobenzoicum subsp. thermosyntrophicum were capable of growth in the presence of CO (Table 1).

Synthesis gas was used as an electron donor of sulphate reduction in bioreactors [49-52]. These studies with mixed microbial communities encountered the same problems as with pure cultures. The major restriction of synthesis gas utilization is the presence of $\mathrm{CO}$, which can range from 5 to over 50\% [53] and its toxicity towards SRB [33]. Du Preez and Maree [50] reported a sulphate reduction rate of $2.4 \mathrm{~g}$ $\mathrm{SO}_{4}{ }^{2-} \mathrm{L}^{-1} \mathrm{~d}^{-1}$ with pure CO. Van Houten et al. $[51,54]$ achieved a sulphate reduction rate in the range of $6-8 \mathrm{~g}$ $\mathrm{SO}_{4}{ }^{2-} \mathrm{L}^{-1} \mathrm{~d}^{-1}$, with a feed gas containing maximally $20 \%$ 
TABLE 1: Tolerance and use of CO by tested sulphate reducers.

\begin{tabular}{|c|c|c|c|c|c|}
\hline & $T\left({ }^{\circ} \mathrm{C}\right)$ & $\begin{array}{l}\mathrm{CO}+\text { carbon sources } \\
\text { besides } \mathrm{CO}\end{array}$ & Products formed & Without sulphate & References \\
\hline $\begin{array}{l}\text { Desulfovibrio vulgaris str. } \\
\text { Madison }\end{array}$ & 37 & $\begin{array}{l}\leq 4,5 \%(+1 \mathrm{mmol} / \mathrm{l} \\
\text { sodium acetate })\end{array}$ & $\mathrm{H}_{2}, \mathrm{CO}_{2}, \mathrm{H}_{2} \mathrm{~S}$ & No growth & {$[38]$} \\
\hline Desulfovibrio baarsii 2st14 & 37 & $1.5 \%(+$ formate $)$ & Alanine, Aspartate Glutamate, $\mathrm{H}_{2} \mathrm{~S}$ & Not reported & {$[39]$} \\
\hline $\begin{array}{l}\text { Desulfovibrio desulfuricans, } \\
\text { Desulfovibrio baculatus, } \\
\text { Desulfovibrio africanus }\end{array}$ & 30 & $\leq 20 \%+$ lactate & $\mathrm{H}_{2}, \mathrm{CO}_{2}, \mathrm{H}_{2} \mathrm{~S}$ & Not tested & {$[40]$} \\
\hline $\begin{array}{l}\text { Desulfosporosinus orientis } \\
\text { (former Desulfotomaculum } \\
\text { orientis) }\end{array}$ & $35-37$ & $\begin{array}{l}\leq 20 \%(+1 \mathrm{mmol} / \mathrm{l} \\
\text { sodium acetate })\end{array}$ & $\mathrm{H}_{2}, \mathrm{CO}_{2}, \mathrm{H}_{2} \mathrm{~S}$ & No growth & {$[8]$} \\
\hline Desulfotomaculum nigrificans & 55 & $\begin{array}{l}\leq 20 \%(+1 \mathrm{mmol} / 1 \\
\text { sodium acetate })\end{array}$ & $\mathrm{H}_{2}, \mathrm{CO}_{2}, \mathrm{H}_{2} \mathrm{~S}$ & No growth & {$[8]$} \\
\hline $\begin{array}{l}\text { Desulfotomaculum } \\
\text { thermobenzoicum subsp. } \\
\text { thermosyntrophicum }\end{array}$ & 55 & $\leq 50-70 \%$ & Acetate, $\mathrm{CO}_{2}, \mathrm{H}_{2} \mathrm{~S}$ & No growth & {$[12,41]$} \\
\hline Desulfotomaculum kuznetsovii & $55-60$ & $\leq 50 \%$ & Acetate, $\mathrm{CO}_{2}, \mathrm{H}_{2} \mathrm{~S}$ & No growth & {$[10,12]$} \\
\hline Desulfotomaculum sp. RHT-3 & 55 & $\leq 50 \%$ & $\mathrm{H}_{2}, \mathrm{CO}_{2}, \mathrm{H}_{2} \mathrm{~S}$ & No growth & {$[10,13]$} \\
\hline $\begin{array}{l}\text { Desulfotomaculum } \\
\text { carboxydivorans CO-1-SRB }\end{array}$ & 55 & $100 \%$ & $\mathrm{H}_{2}, \mathrm{CO}_{2}, \mathrm{H}_{2} \mathrm{~S}$ & $\mathrm{H}_{2}, \mathrm{CO}_{2}$ & {$[13]$} \\
\hline Archaeoglobus fulgidus VC 16 & $75-80$ & $\leq 80 \%$ & Acetate, $\mathrm{CO}_{2}, \mathrm{H}_{2} \mathrm{~S}$, formate (transient) & $\begin{array}{l}\mathrm{CO}_{2} \text {, acetate, } \\
\text { formate } \\
\text { (transient) }\end{array}$ & {$[14,42,43]$} \\
\hline
\end{tabular}

CO. Van Houten et al. [51, 55] showed that CO exerted a toxic effect on the SRB present in the biomass at gas phase CO concentrations between 5 and $20 \%$ as the sulphate reduction rates were limited to $8 \mathrm{~g} \mathrm{SO}_{4}{ }^{2-} \mathrm{L}^{-1} \mathrm{~d}^{-1}$, whereas with $\mathrm{H}_{2} / \mathrm{CO}_{2}$ the maximum sulphate reduction rate achieved was $30 \mathrm{~g} \mathrm{SO}_{4}{ }^{2-} \mathrm{L}^{-1} \mathrm{~d}^{-1}$ [31]. In the presence of $\mathrm{CO}$, a layered biomass structure developed with acetogenic bacteria located at the outside of the biofilm, and SRB located deeper inside the biofilm probably as a protection mechanism towards $\mathrm{CO}$ toxicity $[51,55]$.

2.3. Enzymes of $\mathrm{CO}$ Metabolism and Genomics of COOxidizing SRB. Of all sulphate reducers, only A. fulgidus and Dtm. carboxydivorans were not inhibited by the highest tested $\mathrm{P}_{\mathrm{CO}}$ of 200 and $124 \mathrm{kPa}$, respectively $[14,56]$. Presence of a CO-dehydrogenase in a sulphate reducer does not necessarily mean that it is less sensitive towards CO. Cell extracts of Dtm. thermoacetoxidans revealed a CO-dehydrogenase activity [57] and the whole-genome sequence of $T$. yellowstonii contains a CO-dehydrogenase gene as part of an ACS/CODH cluster (Table 2). However, both bacteria are completely inhibited by less than $2 \%$ of $\mathrm{CO}$ in the gas phase [12]. It might be that the CO-dehydrogenase of $T$. yellowstonii is inactive, since no CO-oxidizing activity was found in cell extracts of this bacterium and it needs acetate as carbon source for growth with $\mathrm{H}_{2}$ or formate as electron donors [58].

In recent reviews devoted to $\mathrm{CO}$-utilization, genomics and $\mathrm{CO}$-sensing mechanisms of anaerobic, aerobic bacteria and Archaea, it was concluded that there is no single mechanism of CO-utilization and CO-inhibition [59-61].
The mechanism of CO-inhibition in particular of sulphate reducers is not completely understood as well. Hydrogenases play a key role in the metabolism of hydrogenotrophic sulphate reducers, and also in the hydrogen-cycling mechanism that was proposed for Desulfovibrio spp. growing on lactate $[62,63]$. It has been shown that $\mathrm{CO}$ is a competitive inhibitor of [FeFe]-hydrogenases where it binds to iron in the active site $[62,63]$. Interestingly, $\mathrm{CO}$ also serves, together with $\mathrm{CN}^{-}$, as a coordinating ligand in the active site of [FeFe]-hydrogenases [64-67].

Inhibition of hydrogenase therefore could potentially explain at least part of the sensitivity of some sulphate reducers towards $\mathrm{CO}$. Other metallo-enzymes could similarly be inhibited by CO. In Dsv. desulfuricans strain B-1388, the effect of $\mathrm{CO}$ on metabolism was studied in more detail. In this bacterium, 5\% CO caused "nonspecific stress" resulting in a lower growth rate, increased content of cytochrome c, increased content of reduced pyridine nucleotides, and a low ATP concentration [68-70]. Therefore, it has been suggested that the function of the CO-dehydrogenase in this organism is to detoxify CO [70]. It was shown that hydrogenases of Clostridium pasteurianum are inhibited by binding of $\mathrm{CO}$ to iron in the active site, but whether this is the sole mechanism of inhibition is not clear [71]. Recent interesting results in this field-CO-tolerant hydrogenases exist that exclude CO from the active site by means of a narrow tunnel that allows hydrogen to pass, but not CO [72]. Since CO binds readily to metals, such as iron, other metal bearing proteins may be similarly affected.

The genome sequence of Dsv. desulfuricans strain B1388 has not been solved, but the genome of seven other 
TABLE 2: CO-dehydrogenase genes in completed genome sequences of sulphate reducers.

\begin{tabular}{|c|c|c|c|c|c|c|c|}
\hline Species & strain & NCBI RefSeq & locus & total & bacterial $^{1}$ & archaeal $^{1}$ & $\mathrm{ACS} / \mathrm{CODH}^{2}$ \\
\hline Archaeoglobus fulgidus & DSM4304 & NC_000917 & $\begin{array}{l}\text { AF1100, 1849, } \\
2397\end{array}$ & 3 & 1 & 2 & 2 \\
\hline Desulfovibrio vulgaris & Hildenborough & NC_002937 & DVU0298 & 1 & 1 & 0 & 0 \\
\hline Desulfovibrio vulgaris & DP4 & NC_008751 & Dvul_1133 & 1 & 1 & 0 & 0 \\
\hline Desulfovibrio vulgaris & Miyazaki F & NC_011769 & DvMF_2233 & 1 & 1 & 0 & 0 \\
\hline Desulfovibrio desulfuricans & G20 & NC_007519 & Dde_3028 & 1 & 1 & 0 & 0 \\
\hline Desulfovibrio desulfuricans & ATCC27774 & NC_011883 & Ddes_0382 & 1 & 1 & 0 & 0 \\
\hline Desulfovibrio salexigens & DSM2638 & NZ_ACCN & DesalDRAFT & 1 & 1 & 0 & 0 \\
\hline Desulfotomaculum reducens & MI-1 & NC_009253 & Dred_0652 & 1 & 1 & 0 & 0 \\
\hline${ }^{3}$ Desulforudis audaxviator & MP104C & NC_010424 & $\begin{array}{l}\text { Daud_0870, } \\
0105\end{array}$ & 2 & 1 & 1 & 2 \\
\hline Desulfococcus oleovorans & Hxd3 & NC_009943 & Dole_1461, 3185 & 2 & 2 & 0 & 1 \\
\hline Syntrophobacter fumaroxidans & MPOB & NC_008554 & $\begin{array}{l}\text { Sfum_2566, } \\
2875\end{array}$ & 2 & 2 & 0 & 1 \\
\hline Desulfatibacillum alkenivorans & AK-01 & NC_011768 & Dalk_0680, 2379 & 2 & 2 & 0 & 1 \\
\hline Thermodesulfovibrio yellowstonii & DSM11347 & NC_011269 & THEYE_A1470 & 1 & 1 & 0 & 1 \\
\hline Desulfobacterium autotrophicum & HRM2 & ${ }^{4} \mathrm{CP} 001087$ & $\begin{array}{l}\text { HRM2_16670, } \\
41010,43430\end{array}$ & 3 & 3 & 0 & 1 \\
\hline Caldivirga maquilingensis & IC-167 & NC_009954 & & 0 & & & \\
\hline Desulfovibrio piger & ATCC29098 & NZ_ABXU & & 0 & & & \\
\hline Desulfotalea psychrophila & LSv54 & NC_006138 & & 0 & & & \\
\hline
\end{tabular}

${ }^{1}$ Number of CO-dehydrogenase genes present in the genome that are homologous to the CO-dehydrogenases commonly found in bacterial ACS/CODH or in archaeal ACS/CODH.

${ }^{2}$ Number of CO-dehydrogenase genes present in a gene context that suggest it is part of acetyl-CoA synthase/CO-dehydrogenase complex.

${ }^{3}$ It is predicted that candidatus Desulforudis audaxviator is a sulphate reducer based upon genome sequence [73].

${ }^{4}$ Genbank accession number for Desulfobacterium autotrophicum.

Desulfovibrio spp. and of ten other dissimilatory sulphate reducers has been sequenced (Table 2). At least 25 more whole-genome sequencing projects on sulphate reducers are ongoing. Of the seven available Desulfovibrio genomes, only Desulfovibrio piger does not contain a CO-dehydrogenase gene homologue. The CO-dehydrogenase gene context appears conserved in Desulfovibrio spp. with $\operatorname{coo} A$ and $\operatorname{coo} C$ homologues, respectively, up- and down-stream of the coos, the gene fragment encoding for $\mathrm{CO}$-dehydrogenase. CooA is a CO-binding transcriptional regulator [74] and $\mathrm{CooC}$ a COdehydrogenase maturation protein $[75,76]$. Interestingly, cooA seems only present in the genomes of Desulfovibrio $s p p$., but in none of the other available genomes of sulphate reducers. Further, CO-dehydrogenase gene context reveals little information about its possible physiological role in the metabolism. A hyd [FeFe]-hydrogenase deletion mutant of Desulfovibrio vulgaris Hildenborough formed transient amounts of CO up to $6000 \mathrm{ppm}$ as part of a fermentation burst. Likely its CO-dehydrogenase is first involved in the production and then in the consumption of $\mathrm{CO}$ by this mutant, with electron transfer possibly linked to a general electron pool [77]. For Dsv. desulfuricans B-1388, it was also shown that $\mathrm{CO}$-dehydrogenase activity in cell extracts increases over time in batch cultures of cells grown with lactate and sulphate as substrates $[35,78]$. In late growth stages, the degradation of cellular material, for example, porphyrins, may release $\mathrm{CO}$ and this results in an increased $\mathrm{CO}$-dehydrogenase expression through the action of CooA.

In the remainder of fully sequenced genomes of sulphate reducers (Table 2) that contain one or more COdehydrogenase genes, the $\mathrm{CO}$-dehydrogenase is either part of an ACS/CODH cluster or is located alone or together with unexpected genes. In this group of sulphate reducers, only Archaeoglobus fulgidus is shown to grow with $\mathrm{CO}$ as substrate [14]. A. fulgidus contains three CO-dehydrogenase genes, two of the type typically found in archaeal ACS/CODH complexes and one homologous to $\operatorname{coos}$ found in bacteria. The archaeal type of CO-dehydrogenases is paired together only with the epsilon subunit of ACS/CODH in A. fulgidus. The beta, gamma, and delta subunits of ACS/CODH appear only once in the genome, separate from the alpha epsilon pairs. It has been speculated that both archaeal type COdehydrogenases are involved in the acetyl-CoA pathway and that oxidation of $\mathrm{CO}$ by $\mathrm{CooS}$ provides electrons for reduction of $\mathrm{CO}_{2}$ to formyl methanofuran and possibly in the reduction of sulphate [14]. Direct experimental evidence for these roles, however, is still lacking.

The presence of multiple $\mathrm{CODH}$ genes in a single genome suggests that multiple physiological roles exist for COdehydrogenase. Besides a role in the ACS/CODH complex, $\mathrm{CO}$ could be oxidized by $\mathrm{CODH}$ and serve as an electron donor for sulfate reduction or CO-dehydrogenase could 
serve to detoxify CO, but clear experimental evidence is lacking. Clearly, the different sulphate reducers respond differently to CO. While based on available whole genome sequences it appears that most sulphate reducers contain a CO-dehydrogenase gene, their sensitivity towards $\mathrm{CO}$ allows speculation that levels of $\mathrm{CO}$ that are encountered by these microorganisms in their natural habitat are limited. It seems that only few sulphate reducers are insensitive towards $\mathrm{CO}$, although more may be found

\section{Synthesis Gas as an Electron Donor for Biotechnological Sulphate Reduction}

According to a cost estimation concerning the use of ethanol and $\mathrm{H}_{2}$ as electron donors for sulphate reduction, ethanol turned out to be cheaper for small-scale installations $\left(<5 \mathrm{kmol} \mathrm{h}^{-1}\right)$, whereas $\mathrm{H}_{2}$ is cheaper for larger installations, assuming the use of a high-purity $\mathrm{H}_{2}$ [55]. Synthesis gas, produced by, for example, steam reforming of natural gas or thermal gasification of coal, oil, biomass, or other organic matter and widely available as by-product of coal burners is a cheap alternative for high-purity $\mathrm{H}_{2}$ [55]. Furthermore, operational costs could be greatly reduced in case of onsite production of synthesis gas from coal, thus minimizing transportation costs.

Several mesophilic full-scale anaerobic sludges, when incubated at $55^{\circ} \mathrm{C}$, revealed the capability of hydrogenogenic CO conversion, whereas direct acetate production was not observed [79]. As mentioned earlier, especially hydrogenogenic CO conversion holds a promise for the use of synthesis gas in biotechnological sulphate reduction, for example, in thermophilic flue gas desulfurization. Therefore, the utilization of $\mathrm{CO}$ as a sole external electron donor in thermophilic $\left(55^{\circ} \mathrm{C}\right)$ sulphate reduction was investigated in lab-scale gas lift bioreactors [80-82]. These reactors were inoculated with mesophilic granular sludge, with a high hydrogenogenic activity on $\mathrm{CO}$ at $55^{\circ} \mathrm{C}$, from which the hydrogenogenic sulphate reducer Dtm. carboxydivorans [13] was isolated.

Thermophilic $\left(50-55^{\circ} \mathrm{C}\right)$ sulphate reduction rates of up to $20 \mathrm{mmol} \mathrm{L}^{-1} \mathrm{~d}^{-1}$ were obtained at hydraulic retention times (HRTs) between 6 and 14 hours [80] showing the potential of sulphate reduction with $\mathrm{CO}$ as an external electron donor. However, due to predominant methanogenic $\mathrm{H}_{2}$ consumption, sulphate reduction rates were generally low. Similar competition effects at $55^{\circ} \mathrm{C}$ leading to methanogenesis have been reported with methanol [83] and $\mathrm{H}_{2} / \mathrm{CO}_{2}$ [84]. Fast growth rates of the methanogens (generation time of 4.5 hours) enabled them to recover from imposed $\mathrm{pH}$ and temperature shocks, and they consumed more than $90 \%$ of the CO-derived $\mathrm{H}_{2}$ [80]. Nevertheless, steep increases in sulphide production in periods with low methanogenic activity suggest that once methanogenesis is eliminated, sulphate reduction with CO-rich gas as electron donor has a great potential [80].

Operation at HRTs shorter than the generation time of the methanogens allowed stable sulphate reduction for prolonged periods, and up to $95 \%$ of the CO-derived $\mathrm{H}_{2}$ was used for sulphate reduction [82]. The achieved sulphate reduction rates of $17 \mathrm{mmol} \cdot \mathrm{L}^{-1} \cdot \mathrm{d}^{-1}$ were limited by the amount of $\mathrm{CO}$ supplied and its conversion efficiency (about $85 \%$ ) at higher CO loads likely results from biomass limitation. Methane production, however, persisted when operating under these conditions and increasing the HRT by returning it to values $>5.5$ hours resulted in a dominance of methanogenesis over sulfate reduction [82].

Although the operation of a thermophilic CO fed gas lift reactor at extremely low HRTs [82] clearly demonstrated the potential of $\mathrm{CO}$ or synthesis gas as an electron donor for biotechnological sulphate reduction, the low biomass concentrations present limited the applicable sulphate loads and thus its practical application. For high-rate biotechnological sulphate reduction processes, biomass retention is a prerequisite, and thus elimination or efficient suppression of methanogenesis is essential. Simple changes in operation conditions, such as $\mathrm{pH}$, temperature, or salinity were ineffective for steering the competition for $\mathrm{H}_{2}$ utilization towards sulphate reduction [80]. Suppression of thermophilic hydrogenogenic methanogenesis has been demonstrated with the use of chemical inhibitors [85] or pretreatment of the sludge prior to inoculation [8688]. However, the use of chemical inhibitors represents a potential risk as they might be released into the environment. Furthermore, adaptation to the inhibitor might result in increased operational costs due to an increasing demand of chemical inhibitors to maintain the same level of inhibition. Weijma and coworkers [89] observed that the application of a continuous dosing of $2 \mathrm{~g} \cdot \mathrm{L}^{-1}$ 2-bromoethanesulfonate to a bioreactor was ineffective for the suppression of methanogenesis, as methanogenesis resumed after two days. In contrast, Sparling et al. [90] successfully inhibited methane formation in an $\mathrm{H}_{2}$ producing anaerobic digester by the addition of $1 \% \mathrm{v} / \mathrm{v}$ acetylene in the headspace.

Heat or acid/base treatment does not inhibit methanogens during reactor operation as would be the case with chemical agents, but rather eliminates methanogens before reactor operation is initiated. Such a pretreatment poses no environmental risk, because no harmful chemicals will be released, and furthermore, such a pretreatment in principle needs to be performed only once; whereas, chemical inhibitors need to be applied constantly most likely at an increased demand. Nevertheless, for the successful suppression of methanogens their complete elimination is a prerequisite, especially fast growing thermophilic methanogens.

In incubations at $55^{\circ} \mathrm{C}$ with Dtm. carboxydivorans, sulphide production occurred at a $\mathrm{P}_{\mathrm{CO}}$ exceeding $100 \mathrm{kPa}$ [56]. However, Dtm. carboxydivorans has a pH-dependent sensitivity for sulphide inhibition, that is, $9 \mathrm{mM}$ sulfide at pH 7.2 and $5 \mathrm{mM}$ at pH 6.5 cause complete inhibition [56]. Thus, most likely not toxicity of $\mathrm{CO}$, but of sulphide determines the sulphate reduction capacity of Dtm. carboxydivorans, as bulk liquid $\mathrm{CO}$ concentrations will likely be kept low due to biological conversion. Therefore, to develop a high-rate sulphate-reducing bioreactor employing Dtm. carboxydivorans, additional features to maintain the sulphide concentration below inhibitory levels are required. To maintain sulphide concentrations sufficiently low, operation at slightly elevated $\mathrm{pH}$-values could be considered or 
application of an alkaline $\mathrm{H}_{2} \mathrm{~S}$ absorber through which the recycle gas is led. The $\mathrm{H}_{2} \mathrm{~S}$ absorbed from the gas phase could be fed to a second micro-aerobic biological reactor, preferably operated at high $\mathrm{pH}$ to minimize consumption of chemicals, in which the sulphide is partially oxidized to elemental sulphur [28]. Another attractive option is the use of $\mathrm{H}_{2} \mathrm{~S}$ extractive membranes [91] placed inside the bioreactor mixed liquor, which could result in direct recovery of elemental sulphur when combining with a $\mathrm{Fe}^{3+}$ containing extraction solution.

Successful application of CO-containing $\mathrm{H}_{2}$-rich synthesis gas in biodesulphurization requires not merely tolerance for the presence of $\mathrm{CO}$, but also the use of $\mathrm{CO}$ within the synthesis gas or its conversion products for sulphate reduction as well. The conversion of $\mathrm{CO}$ to acetate, although a potential substrate for SRB, can be considered a disadvantage as acetate gives rise to elevated effluent COD concentrations and requires the presence of both hydrogenotrophic and acetotrophic SRB. For the maximal utilization of syngas as electron donor, the distinct dominating groups of SRB should be capable of outcompeting other microorganisms that use $\mathrm{H}_{2}$ and acetate. Mesophilic SRB have been shown capable of outcompeting hydrogenotrophic methanogens $[31,92]$. The competition between SRB and methanogens for acetate appears less predictable despite the thermodynamic and kinetic advantages ascribed to SRB [27].

\section{Summary and Perspectives}

Presently, only about ten sulphate-reducing bacteria and one archaeon are able to use $\mathrm{CO}$ as an electron donor for sulphate reduction. Most CO-utilizing sulphate reducers are moderately thermophilic, Gram-positive bacteria. Gramnegative SRB of the Desulfovibrio genus are more sensitive to $\mathrm{CO}$. Still very little is known about the dissimilation and assimilation of $\mathrm{CO}$ by sulphate-reducing bacteria and the toxic effect of $\mathrm{CO}$ on their metabolism. The genomes of some Gram-negative sulphate-reducing bacteria are available as well as that of Archaeoglobus fulgidus. The only genome sequence of Desulfotomaculum sp.-Dtm. reducens is available, but no genes involved in the $\mathrm{CO}$ metabolism are present. The upcoming genomic data will give us information about the presence of the enzymes of CO-utilization among SRB. With genomes from CO-metabolizing Gram-positive sulphate reducers, a comparative analysis can be made of the CO metabolism of Gram-negative and Gram-positive sulphate reducers. Furthermore, more detailed investigation of acetyl-CoA pathway enzymes and hydrogenases of carboxydotrophic SRB might give more insight to COutilization by SRB.

The occurrence of thermophilic microorganisms capable of a high-rate hydrogenogenic CO conversion as well as sulfate reduction in the presence of high levels of CO enables the use of CO containing synthesis gas in biotechnological desulphurisation. Successful application of $\mathrm{H}_{2}$-rich synthesis gas in biodesulphurisation, without the need for prior purification, requires tolerance for the presence of CO. Furthermore, it would be most beneficial to the overall sulfate reduction process if $\mathrm{CO}$ within the synthesis gas is used for sulphate reduction as well. Thus, both toxicity and potential metabolic use of $\mathrm{CO}$ as an electron donor are important factors governing the utilization potential of COrich synthesis gas for biotechnological sulphate reduction. In that respect, the recent discovery of CO tolerant SRB, such as Dtm. carboxydivorans, indicates that CO-rich synthesis gas holds promise as a cheap alternative electron donor for biodesulphurisation. Nevertheless, in order to enable highrate biotechnological sulphate reduction employing Dtm. carboxydivorans, special attention should be directed to the competition for the electron donor with methanogens as well as inhibitory effects of the hydrogen sulphide formed.

\section{Acknowledgments}

This research was supported by the Technology Foundation, the applied science division (STW), the Chemical Science division (CW), and the Earth and Life Sciences division (ALW) of the Netherlands Organization for Scientific Research (NWO), Paques B.V. (Balk, The Netherlands) and Shell Global Solutions (Amsterdam, The Netherlands).

\section{References}

[1] J. R. Postgate, The Sulphate-Reducing Bacteria, Cambridge University, Cambridge, UK, 1979.

[2] G. Muyzer and A. J. M. Stams, "The ecology and biotechnology of sulphate-reducing bacteria," Nature Reviews Microbiology, vol. 6, no. 6, pp. 441-454, 2008.

[3] B. Ollivier, R. Cord-Ruwisch, E. C. Hatchikian, and J. L. Garcia, "Characterization of Desulfovibrio fructosovorans sp. nov," Archives of Microbiology, vol. 149, no. 5, pp. 447-450, 1988.

[4] A. Sass, H. Rutters, H. Cypionka, and H. Sass, "Desulfobulbus mediterraneus sp. nov., a sulphate-reducing bacterium growing on mono- and disaccharides," Archives of Microbiology, vol. 177, pp. 468-474.

[5] S. Baena, M.-L. Fardeau, M. Labat, B. Ollivier, J.-L. Garcia, and B. K. C. Patel, "Desulfovibrio aminophilus sp. nov., a novel amino acid degrading and sulfate reducing bacterium from an anaerobic dairy wastewater lagoon," Systematic and Applied Microbiology, vol. 21, no. 4, pp. 498-504, 1998.

[6] A. J. M. Stams, T. A. Hansen, and G. W. Skyring, "Utilization of amino acids as energy substrates by two marine Desulfovibrio strains," FEMS Microbiology Ecology, vol. 31, no. 1, pp. 11-15, 1985.

[7] F. Widdel and T. A. Hansen, "The dissimilatory sulfate- and sulfurreducing bacteria," in The Prokaryotes, A. Balows, H. G. Trüper, M. Dworkin, W. Harder, and K.-H. Schleifer, Eds., pp. 583-624, Springer, Berlin, Germany, 2nd edition, 1992.

[8] R. Klemps, H. Cypionka, F. Widdel, and N. Pfennig, "Growth with hydrogen, and further physiological characteristics of Desulfotomaculum species," Archives of Microbiology, vol. 143, no. 2, pp. 203-208, 1985.

[9] H. J. Nanninga and J. C. Gottschal, "Properties of Desulfovibrio carbinolicus sp. nov. and other sulfate-reducing bacteria isolated from an anaerobic-purification plant," Applied and Environmental Microbiology, vol. 53, no. 4, pp. 802-809, 1987.

[10] T. N. Nazina, A. E. Ivanova, L. P. Kanchaveli, and E. P. Rozanova, "A new sporeforming thermophilic methylotrophic sulfate-reducing bacterium, Desulfotomaculum kuznetsovii sp. nov.", Mikrobiologia, vol. 57, pp. 823-827, 1988 (Russian). 
[11] T. N. Nazina, T. P. Turova, A. B. Poltaraus, et al., "Phylogenetic position and chemotaxonomic characteristics of the thermophilic sulfate-reducing bacterium Desulfotomaculum kuznetsovii," Mikrobiologiya, vol. 68, no. 1, pp. 92-99, 1999.

[12] S. N. Parshina, S. Kijlstra, A. M. Henstra, J. Sipma, C. M. Plugge, and A. J. M. Stams, "Carbon monoxide conversion by thermophilic sulfate-reducing bacteria in pure culture and in co-culture with Carboxydothermus hydrogenoformans," Applied Microbiology and Biotechnology, vol. 68, no. 3, pp. 390-396, 2005.

[13] S. N. Parshina, J. Sipma, Y. Nakashimada, et al., "Desulfotomaculum carboxydivorans sp. nov., a novel sulfate-reducing bacterium capable of growth at 100\% CO," International Journal of Systematic and Evolutionary Microbiology, vol. 55, no. 5, pp. 2159-2165, 2005.

[14] A. M. Henstra, C. Dijkema, and A. J. M. Stams, "Archaeglobus fulgidus couples CO oxidation to sulfate reduction and acetogenesis with transietnt formate accumulation," Environmental Microbiology, vol. 9, pp. 1836-1841, 2007.

[15] Y. Tanimoto and F. Bak, "Anaerobic degradation of methylmercaptan and dimethyl sulfide by newly isolated thermophilic sulfate-reducing bacteria," Applied and Environmental Microbiology, vol. 60, no. 7, pp. 2450-2455, 1994.

[16] F. Aeckersberg, F. A. Rainey, and F. Widdel, "Growth, natural relationships, cellular fatty acids and metabolic adaptation of sulfate-reducing bacteria that utilize long-chain alkanes under anoxic conditions," Archives of Microbiology, vol. 170, no. 5, pp. 361-369, 1998.

[17] C. M. So and L. Y. Young, "Isolation and characterization of a sulfate-reducing bacterium that anaerobically degrades alkanes," Applied and Environmental Microbiology, vol. 65, no. 7, pp. 2969-2976, 1999.

[18] I. A. Davidova, K. E. Duncan, O. K. Choi, and J. M. Suflita, "Desulfoglaeba alkanexedens gen. nov., sp. nov. an n-alkanedegrading, sulfate-reducing bacterium," International Journal of Systematic and Evolutionary Microbiology, vol. 56, no. 12, pp. 2737-2742, 2006.

[19] C. Cravo-Laureau, R. Matheron, J.-L. Cayol, C. Joulian, and A. Hirschler-Réa, "Desulfatibacillum aliphaticivorans gen. nov., sp. nov., an $n$-alkane- and $n$-alkene-degrading, sulfatereducing bacterium," International Journal of Systematic and Evolutionary Microbiology, vol. 54, no. 1, pp. 77-83, 2004.

[20] V. Grossi, C. Cravo-Laureau, A. Meóu, D. Raphel, F. Garzino, and A. Hirschler-Réa, "Anaerobic 1-alkene metabolism by the alkane- and alkene-degrading sulfate reducer Desulfatibacillum aliphaticivorans strain CV2803T," Applied and Environmental Microbiology, vol. 73, no. 24, pp. 7882-7890, 2007.

[21] O. Kniemeyer, F. Musat, S. M. Sievert, et al., "Anaerobic oxidation of short-chain hydrocarbons by marine sulphatereducing bacteria," Nature, vol. 449, no. 7164, pp. 898-901, 2007.

[22] S. Schnell, F. Bak, and N. Pfennig, "Anaerobic degradation of aniline and dihydroxybenzenes by newly isolated sulfatereducing bacteria and description of Desulfobacterium anilini," Archives of Microbiology, vol. 152, no. 6, pp. 556-563, 1989.

[23] R. Rabus, R. Nordhaus, W. Ludwig, and F. Widdel, "Complete oxidation of toluene under strictly anoxic conditions by a new sulfate-reducing bacterium," Applied and Environmental Microbiology, vol. 59, no. 5, pp. 1444-1451, 1993.

[24] G. Harms, K. Zengler, R. Rabus, et al., "Anaerobic oxidation of $o$-xylene, $m$-xylene, and homologous alkylbenzenes by new types of sulfate-reducing bacteria," Applied and Environmental Microbiology, vol. 65, no. 3, pp. 999-1004, 1999.
[25] B. Morasch, B. Schink, C. C. Tebbe, and R. U. Meckenstock, "Degradation of $o$-xylene and $m$-xylene by a novel sulfatereducer belonging to the genus Desulfotomaculum," Archives of Microbiology, vol. 181, no. 6, pp. 407-417, 2004.

[26] B. Schink and M. Friedrich, "Phosphite oxidation by sulphate reduction," Nature, vol. 406, no. 6791, p. 37, 2000.

[27] P. N. L. Lens, A. Visser, A. J. H. Janssen, L. W. Hulshoff Pol, and G. Lettinga, "Biotechnological treatment of sulfate-rich wastewaters," Critical Reviews in Environmental Science and Technology, vol. 28, no. 1, pp. 41-88, 1998.

[28] A. J. H. Janssen, H. Dijkman, and G. Janssen, "Novel biological processes for the removal of $\mathrm{H}_{2} \mathrm{~S}$ and $\mathrm{SO}_{2}$ from gas streams," in Environmental Technologies to Treat Sulfur Pollutions; Principles and Engineering, P. N. L. Lens and L. W. Hulshoff Pol, Eds., pp. 265-280, IWA Publishing, London, UK, 2000.

[29] B. H. G. W. van Houten, K. Roest, V. A. Tzeneva, H. Dijkman, H. Smidt, and A. J. M. Stams, "Occurrence of methanogenesis during start-up of a full-scale synthesis gas-fed reactor treating sulfate and metal-rich wastewater," Water Research, vol. 40, no. 3, pp. 553-560, 2006.

[30] B. Johnson, "Biological removal of sulfurous compounds from inorganic wastewaters," in Environmental Technologies to Treat Sulfur Pollutions; Principles and Engineering, P. N. L. Lens and L. W. Hulshoff Pol, Eds., pp. 175-205, IWA Publishing, London, UK, 2000.

[31] R. T. van Houten, L. W. Hulshoff Pol, and G. Lettinga, "Biological sulphate reduction using gas-lift reactors fed with hydrogen and carbon dioxide as energy and carbon source," Biotechnology and Bioengineering, vol. 44, no. 5, pp. 586-594, 1994.

[32] M. S. Graboski, "The production of synthesis gas from methane, coal and biomass," in Catalytic Conversion of Synthesis Gas and Alcohols to Chemicals, R. G. Herman, Ed., pp. 37-52, Plenum Press, New York, NY, USA, 1984.

[33] J. Sipma, A. M. Henstra, S. M. Parshina, P. N. Lens, G. Lettinga, and A. J. Stams, "Microbial CO conversions with applications in synthesis gas purification and bio-desulfurization," Critical Reviews in Biotechnology, vol. 26, no. 1, pp. 41-65, 2006.

[34] G. Mörsdorf, K. Frunzke, D. Gadkari, and O. Meyer, "Microbial growth on carbon monoxide," Biodegradation, vol. 3, no. 1, pp. 61-82, 1992.

[35] M. N. Davidova, N. B. Tarasova, F. K. Mukhitova, and I. U. Karpilova, "Carbon monoxide in metabolism of anaerobic bacteria," Canadian Journal of Microbiology, vol. 40, no. 6, pp. 417-425, 1994.

[36] T. G. Sokolova, A. M. Henstra, J. Sipma, S. N. Parshina, A. J. M. Stams, and A. V. Lebedinsky, "Diversity and ecophysiological features of thermophilic carboxydotrophic anaerobes," FEMS Microbiology Ecology, vol. 68, no. 2, pp. 131-141, 2009.

[37] J. P. Amend and E. L. Shock, "Energetics of overall metabolic reactions of thermophilic and hyperthermophilic Archaea and Bacteria," FEMS Microbiology Reviews, vol. 25, no. 2, pp. 175-243, 2001.

[38] F. S. Lupton, R. Conrad, and J. G. Zeikus, "CO metabolism of Desulfovibrio vulgaris strain Madison: physiological function in the absence or presence of exogeneous substrates," FEMS Microbiology Letters, vol. 23, no. 2-3, pp. 263-268, 1984.

[39] K. Jansen, R. K. Thauer, F. Widdel, and G. Fuchs, "Carbon assimilation pathways in sulfate reducing bacteria. Formate, carbon dioxide, carbon monoxide, and acetate assimilation by Desulfovibrio baarsii," Archives of Microbiology, vol. 138, no. 3, pp. 257-262, 1984. 
[40] I. I. Karpilova, M. N. Davydova, and M. I. Beliaeva, "The effect of carbon monoxide on the growth of sulfate-reducing bacteria and their oxidation of this substrate," Nauchnye Doklady Vysshei Shkoly. Biologicheskie Nauki, no. 1, pp. 85-88, 1983 (Russian).

[41] C. M. Plugge, M. Balk, and A. J. M. Stams, "Desulfotomaculum thermobenzoicum subsp. thermosyntrophicum subsp. nov., a thermophilic, syntrophic, propionate-oxidizing, sporeforming bacterium," International Journal of Systematic and Evolutionary Microbiology, vol. 52, no. 2, pp. 391-399, 2002.

[42] K. O. Stetter, G. Laurer, M. Thomm, and A. Neuner, "Isolation of extremely thermophilic sulfate reducers: evidence for a novel branch of archaebacteria," Science, vol. 236, no. 4803, pp. 822-824, 1987.

[43] K. O. Stetter, "Archaeoglobus fulgidus gen. nov., sp. nov.: a new taxon of extremely thermophilic archaebacteria," Systematic and Applied Microbiollogy, vol. 10, pp. 172-173, 1988.

[44] V. A. Svetlichny, T. G. Sokolova, M. Gerhardt, M. Ringpfeil, N. A. Kostrikina, and G. A. Zavarzin, "Carboxydothermus hydrogenoformans gen. nov., sp. nov., a CO-utilizing thermophilic anaerobic bacterium from hydrothermal environments of Kunashir Island," Systematic and Applied Microbiology, vol. 14, no. 3, pp. 254-260, 1991.

[45] L. L. Campbell and J. R. Postgate, "Classification of the sporeforming sulphate-reducing bacteria," Bacteriology Reviews, vol. 29, pp. 359-363, 1965.

[46] J. Kuever and F. A. Rainey, "Genus Desulfotomaculum Campbell and Postgate 1965, 361 AL," in Bergey's Manual of Systematic Bacteriology, P. De Vos, G. M. Garrity, D. Jones, F. A. Reiney, K.-H. Schleifer, and W. B. Whitman, Eds., vol. 3, pp. 989-996, 2009.

[47] K. Mori, M. Hatsu, R. Kimura, and K. Takamizawa, "Effect of heavy metals on the growth of a methanogen in pure culture and coculture with a sulfate-reducing bacterium," Journal of Bioscience and Bioengineering, vol. 90, no. 3, pp. 260-265, 2000.

[48] F. K. Mukhitova, I. N. Ryazantseva, I. I. Karpilova, and M. I. Belyaeva, "The utilization of carbon monoxide by bacteria of Desulfovibrio genus," Izevestiya Akademii Nauk SSSR, no. 6, pp. 944-948, 1983 (Russian).

[49] L. A. du Preez, J. P. Odendaal, J. P. Maree, and M. Ponsonby, "Biological removal of sulphate from industrial effluents using producer gas as energy source," Environmental Technology, vol. 13, no. 9, pp. 875-882, 1992.

[50] L. A. du Preez and J. P. Maree, "Pilot-scale biological sulphate and nitrate removal utilizing producer gas as energy source," Water Science and Technology, vol. 30, no. 12, pp. 275-285, 1994.

[51] R. T. van Houten, H. van der Spoel, A. C. van Aelst, L. W. Hulshoff Pol, and G. Lettinga, "Biological sulfate reduction using synthesis gas as energy and carbon source," Biotechnology and Bioengineering, vol. 50, no. 2, pp. 136-144, 1996.

[52] A. M. Henstra, J. Sipma, A. Rinzema, and A. J. Stams, "Microbiology of synthesis gas fermentation for biofuel production," Current Opinion in Biotechnology, vol. 18, no. 3, pp. 200-206, 2007.

[53] R. H. Perry, D. W. Green, and J. O. Maloney, Perry's Chemical Engineers' Handbook, Graw-Hill, New York, NY, USA, 1997.

[54] R. T. van Houten, Biological sulphate reduction with synthesis gas, Ph.D. thesis, Wageningen Academic Publishers, Wageningen, The Netherlands, 1996.
[55] R. T. van Houten and G. Lettinga, "Biological sulphate reduction with synthesis gas: microbiology and technology," in Progress in Biotechnology, R. H. Wijffels, R. M. Buitelaar, C. Bucke, and J. Tramper, Eds., pp. 793-799, Elsevier, Amsterdam, The Netherlands, 1996.

[56] J. Sipma, M. B. Osuna, S. N. Parshina, G. Lettinga, A. J. M. Stams, and P. N. L. Lens, " $\mathrm{H}_{2}$ enrichment from synthesis gas by Desulfotomaculum carboxydivorans for potential applications in synthesis gas purification and biodesulfurization," Applied Microbiology and Biotechnology, vol. 76, no. 2, pp. 339-347, 2007.

[57] H. Min and S. H. Zinder, "Isolation and characterization of a thermophilic sulfate-reducing bacterium Desulfotomaculum thermoacetoxidans sp. nov.," Archives of Microbiology, vol. 153, no. 4, pp. 399-404, 1990.

[58] E. A. Henry, R. Devereux, J. S. Maki, et al., "Characterization of a new thermophilic sulfate-reducing bacterium. Thermodesulfovibrio yellowstonii, gen. nov. and sp. nov.: its phylogenetic relationship to Thermodesulfobacterium commune and their origins deep within the bacterial domain," Archives of Microbiology, vol. 161, no. 1, pp. 62-69, 1994.

[59] G. P. Roberts, H. Youn, and R. L. Kerby, "CO-Sensing mechanisms," Microbiology and Molecular Biology Reviews, vol. 68, no. 3, pp. 453-473, 2004.

[60] G. M. King and C. F. Weber, "Distribution, diversity and ecology of aerobic CO-oxidizing bacteria," Nature Reviews Microbiology, vol. 5, no. 2, pp. 107-118, 2007.

[61] E. Oelgeschläger and M. Rother, "Carbon monoxidedependent energy metabolism in anaerobic bacteria and archaea," Archives of Microbiology, vol. 190, no. 3, pp. 257-269, 2008.

[62] J. M. Odom and H. D. Peck Jr., "Hydrogen cycling as a general mechanism for energy coupling in the sulfate-reducing bacteria. Desulfovibrio sp," FEMS Microbiology Letters, vol. 12, no. 1, pp. 47-50, 1981.

[63] J. F. Heidelberg, R. Seshadri, S. A. Haveman, et al., "The genome sequence of the anaerobic, sulfate-reducing bacterium Desulfovibrio vulgaris Hildenborough," Nature Biotechnology, vol. 22, no. 5, pp. 554-559, 2004.

[64] A. J. Pierik, M. Hulstein, W. R. Hagen, and S. P. J. Albracht, "A low-spin iron with $\mathrm{CN}$ and $\mathrm{CO}$ as intrinsic ligands forms the core of the active site in [Fe]-hydrogenases," European Journal of Biochemistry, vol. 258, no. 2, pp. 572-578, 1998.

[65] Y. Nicolet, C. Piras, P. Legrand, C. E. Hatchikian, and J. C. Fontecilla-Camps, "Desulfovibrio desulfuricans iron hydrogenase: the structure shows unusual coordination to an active site Fe binuclear center," Structure, vol. 7, no. 1, pp. 13-23, 1999.

[66] B. J. Lemon and J. W. Peters, "Iron-only hydrogenases," in Handbook of Metalloproteins, A. Messerschmidt, R. Huber, T. Poulus, and K. Wieghardt, Eds., pp. 738-751, Wiley, New York, NY, USA, 2001.

[67] C. Greco, M. Bruschi, J. Heimdal, P. Fantucci, L. de Gioia, and U. Ryde, "Structural insights into the active-ready form of [FeFe]-hydrogenase and mechanistic details of its inhibition by carbon monoxide," Inorganic Chemistry, vol. 46, no. 18, pp. 7256-7258, 2007.

[68] S. Y. Mityashina and M. N. Davydova, "Effects of carbon monoxide on the nucleotide content of Desulfovibrio desulfuricans B-1388," Applied Biochemistry and Microbiology, vol. 31, pp. 547-549, 1995. 
[69] S. Y. Mityashina and M. N. Davydova, "Characteristics of the energy state of Desulfovibrio desulfuricans B-1388 cells growing in lactate-sulfate medium under an atmosphere of argon plus carbon monoxide," Microbiology, vol. 67, pp. 471-475, 1998 (Russian).

[70] M. Davydova, R. Sabirova, N. Vylegzhanina, and N. Tarasova, "Carbon monoxide and oxidative stress in Desulfovibrio desulfuricans B-1388," Journal of Biochemical and Molecular Toxicology, vol. 18, no. 2, pp. 87-91, 2004.

[71] B. J. Lemon and J. W. Peters, "Binding of exogenously added carbon monoxide at the active site of the irononly hydrogenase (CpI) from Clostridium pasteurianum," Biochemistry, vol. 38, no. 40, pp. 12969-12973, 1999.

[72] P. P. Liebgott, F. Leroux, B. Burlat, et al., "Relating diffusion along the substrate tunnel and oxygen sensitivity in hydrogenase," Nature Chemical Biology, vol. 6, no. 1, pp. 63-70, 2010.

[73] D. Chivian, E. L. Brodie, E. J. Alm, et al., "Environmental genomics reveals a single-species ecosystem deep within earth," Science, vol. 322, no. 5899, pp. 275-278, 2008.

[74] D. Shelver, R. L. Kerby, Y. He, and G. P. Roberts, "CooA, a $\mathrm{CO}$-sensing transcription factor from Rhodospirillum rubrum, is a CO-binding heme protein," Proceedings of the National Academy of Sciences of the United States of America, vol. 94, no. 21, pp. 11216-11220, 1997.

[75] J. D. Fox, R. L. Kerby, G. P. Roberts, and P. W. Ludden, "Characterization of the CO-induced, CO-tolerant hydrogenase from Rhodospirillum rubrum and the gene encoding the large subunit of the enzyme," Journal of Bacteriology, vol. 178, no. 6, pp. 1515-1524, 1996.

[76] R. L. Kerby, P. W. Ludden, and G. P. Roberts, "Carbon monoxide-dependent growth of Rhodospirillum rubrum," Journal of Bacteriology, vol. 177, no. 8, pp. 2241-2244, 1995.

[77] G. Voordouw, "Carbon monoxide cycling by Desulfovibrio vulgaris Hildenborough," Journal of Bacteriology, vol. 184, no. 21, pp. 5903-5911, 2002.

[78] N. B. Tarasova and M. I. Belyaeva, "The CO dehydrogenase activity of Desulfovibrio desulfuricans growing under chemoorganotrophic and chemolithoheterotrophic conditions," Microbiology, vol. 67, no. 5, pp. 504-508, 1998.

[79] J. Sipma, P. N. L. Lens, A. J. M. Stams, and G. Lettinga, "Carbon monoxide conversion by anaerobic bioreactor sludges," FEMS Microbiology Ecology, vol. 44, no. 2, pp. 271-277, 2003.

[80] J. Sipma, G. Lettinga, A. J. M. Stams, and P. N. L. Lens, "Hydrogenogenic CO conversion in a moderately thermophilic $\left(55^{\circ} \mathrm{C}\right)$ sulfate-fed gas lift reactor: competition for $\mathrm{CO}$-derived $\mathrm{H}_{2}$," Biotechnology Progress, vol. 22, no. 5, pp. 1327-1334, 2006.

[81] J. Sipma, Microbial hydrogenotrophic CO conversions: applications in synthesis gas purification and biodesulfurization, Ph.D. thesis, Wageningen University, Wageningen, The Netherlands, 2006.

[82] J. Sipma, M. B. Osuna, G. Lettinga, A. J. M. Stams, and P. N. L. Lens, "Effect of hydraulic retention time on sulfate reduction in a carbon monoxide fed thermophilic gas lift reactor," Water Research, vol. 41, no. 9, pp. 1995-2003, 2007.

[83] M. V. G. Vallero, R. H. M. Treviño, P. L. Paulo, G. Lettinga, and P. N. L. Lens, "Effect of sulfate on methanol degradation in thermophilic $\left(55^{\circ} \mathrm{C}\right)$ methanogenic UASB reactors," Enzyme and Microbial Technology, vol. 32, no. 6, pp. 676-687, 2003.

[84] R. T. van Houten, S. Y. Yun, and G. Lettinga, "Thermophilic sulphate and sulphite reduction in lab-scale gas-lift reactors using $\mathrm{H}_{2}$ and $\mathrm{CO}_{2}$ as energy and carbon source," Biotechnology and Bioengineering, vol. 55, no. 5, pp. 807-814, 1997.
[85] J. C. M. Scholten, R. Conrad, and A. J. M. Stams, "Effect of 2-bromo-ethane sulfonate, molybdate and chloroform on acetate consumption by methanogenic and sulfate-reducing populations in freshwater sediment," FEMS Microbiology Ecology, vol. 32, no. 1, pp. 35-42, 2000.

[86] J. Sipma, R. J. W. Meulepas, S. N. Parshina, A. J. M. Stams, G. Lettinga, and P. N. L. Lens, "Effect of carbon monoxide, hydrogen and sulfate on thermophilic $\left(55^{\circ} \mathrm{C}\right)$ hydrogenogenic carbon monoxide conversion in two anaerobic bioreactor sludges," Applied Microbiology and Biotechnology, vol. 64, no. 3, pp. 421-428, 2004.

[87] S.-E. Oh, S. van Ginkel, and B. E. Logan, "The relative effectiveness of $\mathrm{pH}$ control and heat treatment for enhancing biohydrogen gas production," Environmental Science and Technology, vol. 37, no. 22, pp. 5186-5190, 2003.

[88] C.-C. Chen, C.-Y. Lin, and M.-C. Lin, "Acid-base enrichment enhances anaerobic hydrogen production process," Applied Microbiology and Biotechnology, vol. 58, no. 2, pp. 224-228, 2002.

[89] J. Weijma, E. A. A. Bots, G. Tandlinger, A. J. M. Stams, L. W. Hulshoff Pol, and G. Lettinga, "Optimisation of sulphate reduction in a methanol-fed thermophilic bioreactor," Water Research, vol. 36, no. 7, pp. 1825-1833, 2002.

[90] R. Sparling, D. Risbey, and H. M. Poggi-Varaldo, "Hydrogen production from inhibited anaerobic composters," International Journal of Hydrogen Energy, vol. 22, no. 6, pp. 563-566, 1997.

[91] A. de Smul and W. Verstraete, "The phenomenology and the mathematical modeling of the silicone-supported chemical oxidation of aqueous sulfide to elemental sulfur by ferric sulphate," Journal of Chemical Technology and Biotechnology, vol. 74, no. 5, pp. 456-466, 1999.

[92] R. Cord-Ruwisch, H.-J. Seitz, and R. Conrad, "The capacity of hydrogenotrophic anaerobic bacteria to compete for traces of hydrogen depends on the redox potential of the terminal electron acceptor," Archives of Microbiology, vol. 149, no. 4, pp. 350-357, 1988. 

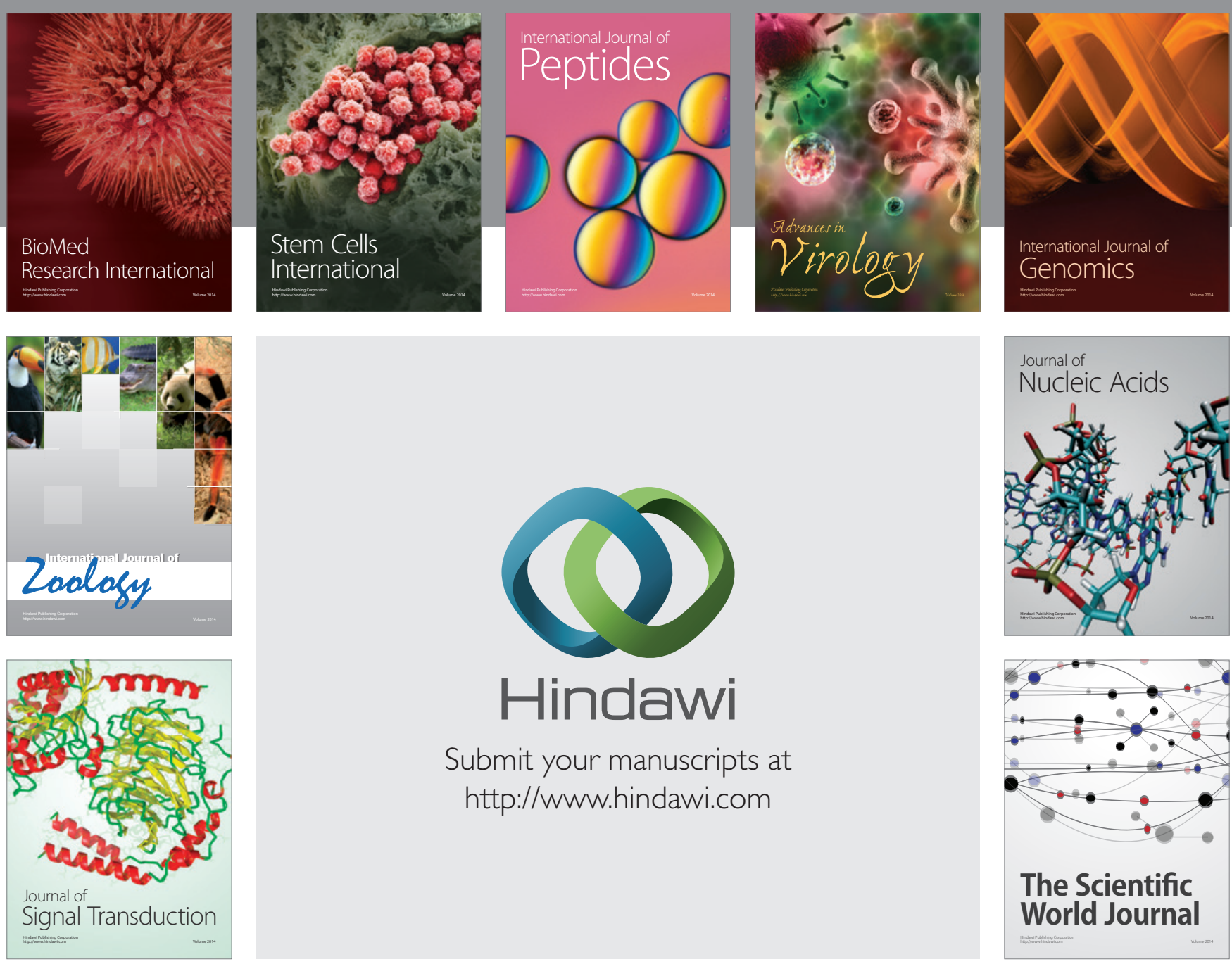

Submit your manuscripts at

http://www.hindawi.com
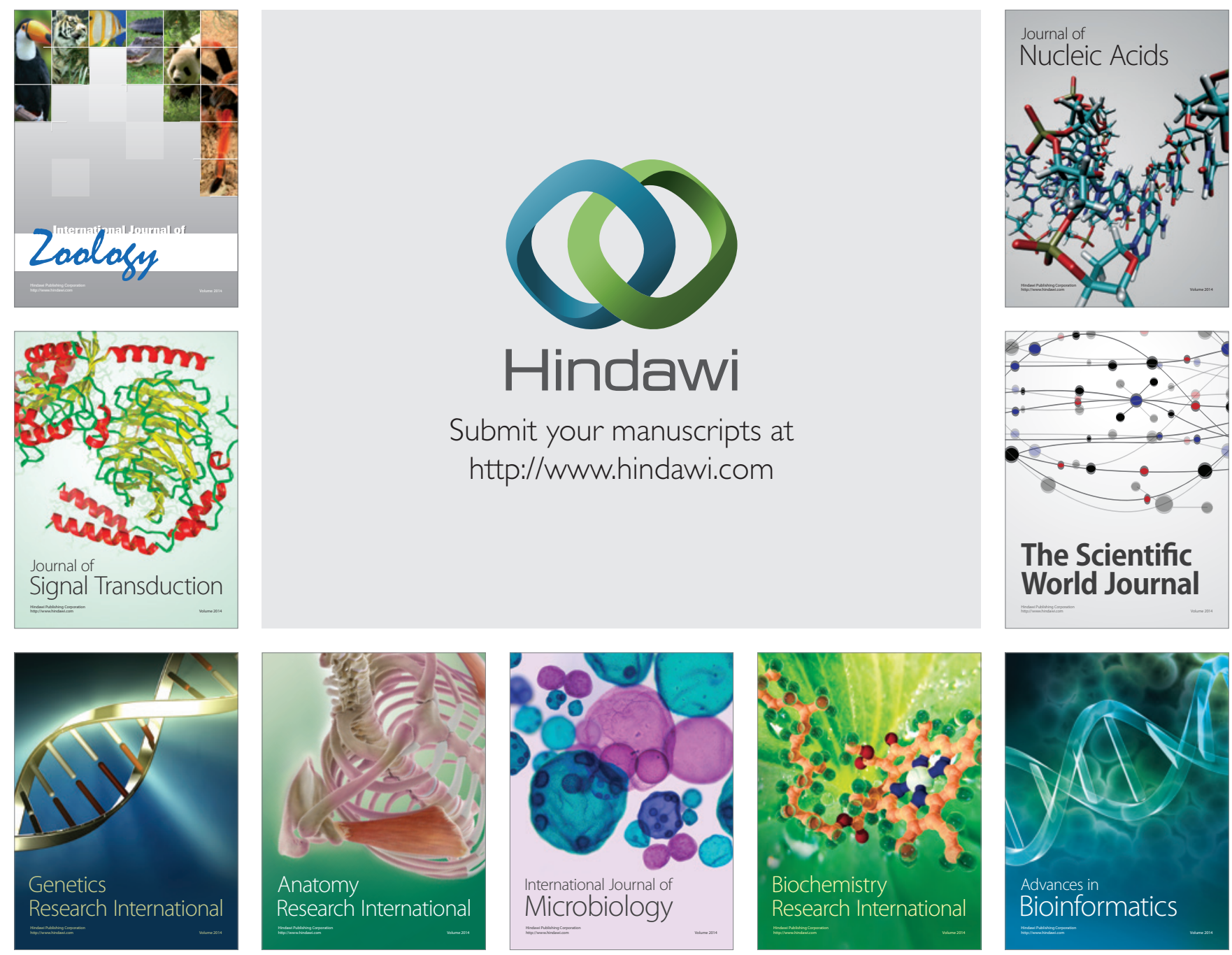

The Scientific World Journal
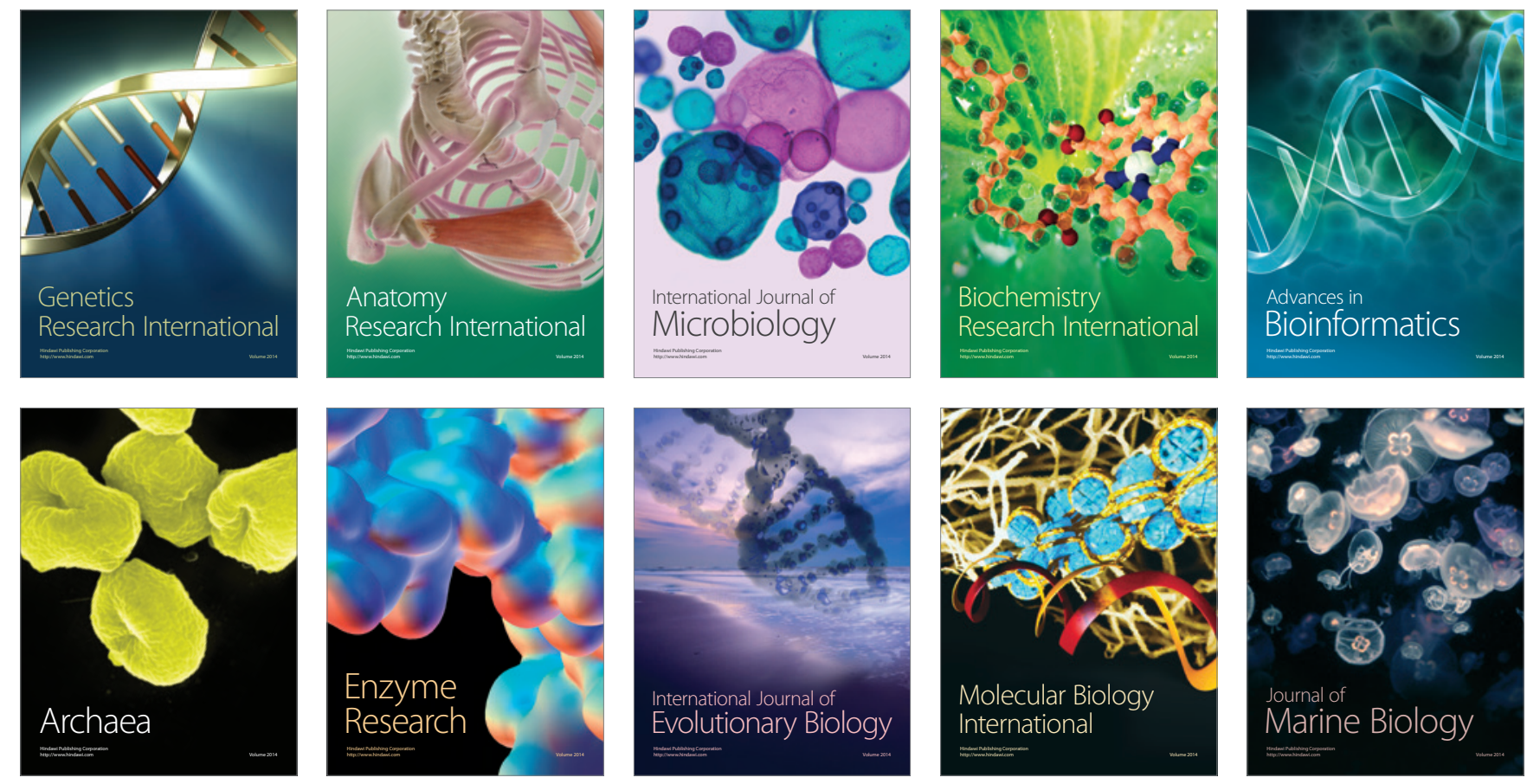